\title{
Permasalahan Pendidikan Islam di Lembaga Pendidikan Madrasah
}

\author{
Ismi Adelia ${ }^{1}$, Oki Mitra $^{2}$ \\ 1,2 Fakultas Tarbiyah, LAIN Kerinci \\ e-mail: ismiadelia@iainkerinci.ac.id
}

\begin{abstract}
ABSTRAK. Permasalahan yang dihadapi pendidikan di Indonesia secara umum ini, adalah kualitas, relevansi, elitisme, dan menajemen. Permasalahan ini terjadi pada pendidikan secara umum di Indonesia, termasuk pendidikan islam yang di nilai justru lebih besar problematikanya. Metodelogi dalam penelitian ini adalah penelitian studi kasus dalam arti penelitian ini difokuskan pada kasus (fenomena) yang kemudian di pahami dan di analisis secara mendalam. Metode penelitian ini digunakan untuk mendiskripsikan secara holistik dan komperhensif tentang gejala dan peristiwa dalam permasalahan pendidikan islam khususnya Madrasah. Tujuan penulisan artikel ini adalah untuk mengungkapkan permasalahan yang ada pada Madrasah sehingga bisa menjadi pedoman untuk kedepannya agar madrasah bisa lebih baik dan mandiri. Adapun hasil Penelitian dari Bentuk permasalahan Pendidikan Islam di Madrasah antara lain adalah Lemahnya akhlak siswa di Madrasah, kurangnya kontribusi siswa dalam menyiarkan ajaran Islam di masyarakat, Berkurangnya minat siswa di bandingkan pada sebelumnya, dan banyak yang memilih untuk pindah ke sekolah umum. Adapun Pembahasan dari penelitian ini adalah permasalahan yang dihadapi oleh Madrasah dalam pendidikan Islam dengan melihat dari dua sisi permasalahan pokok yaitu permasalahan internal dan permasalahan eksternal. Faktor lain yang secara umum dihadapi oleh Madrasah adalah masyarakat agaknya kurang memiliki kebebasan untuk mengelola dengan caranya sendiri, karena hampir semua hal yang berkaitan dengan pendidikan sudah ditentukan oleh pemegang otoritas pendidikan.
\end{abstract}

Kata kunci: Pendidikan Islam; Madrasah; Permasalahan Madrasah

\section{PENDAHULUAN}

Kita semua telah banyak mengenal dengan berbagai bentuk dan jenis lembaga atau institusi pendidikan islam yang ada di Indonesia tercinta ini contohnya antara lain pendidikan Pondok esantren, Madrasah-madrasah Negeri dan swasta, Sekolah umum yang bercirikan Islam atau yang lebih di kenal saat ini dengan sekolah islam terpadu (SIT), Perguruan tinggi islam negeri dan swasta serta jenis jenis pendidikan islam luar sekolah lainnya, seperti taman taman pendidikan Al-Qur'an dan sebagainya. Semua itu, sesungguhnya merupakan asset dan salah satu dari konfigurasi system pendidikan nasional yang ada di Indonesia raya ini, bahkan sebagiannya sudah sejak lama adanya. Keberadaan lembaga lembaga pendidikan tersebut, sebagai khazanah pendidikan dan diharapkan dapat membangun dan memberdayakan umat islam di Indonesia secara optimal, tetapi pada kenyataannya dalam dunia pendidikan islam di Indonesia tidak memiliki kesempatan yang luas untuk bersaing dengan lembaga pendidikan islam lainnya dalam rangka membangun umat islam yang besar di Indonesia ini. Tentunya, sebagai pelaksana program pendidikan, lembaga pendidikan 
tersebut adalah pemeran utama untuk melaksanakan program program pendidikan tersebut. Dalam pelaksanaan program program serta tujuan yang telah di sepakati oleh lembaga pendidikan tersebut tentunya tidak bisa terlepas dari berbagai problematika maupun persoalan persoalan lain yang harus di selesaikan oleh lembaga pendidikan termasuk lembaga lembaga pendidikan islam (Burhanuddin, 2011). Lembaga pendidikan madrasah di Indonesia seperti organisasi (institutusi) dalam dunia pendidikan islam berkembang sesuai dengan irama sejarah islam itu sendiri bukan hanya dalam kualitas tetapi fluktasi sejarah telah merefleksika pertumbuhan institusi pendidikan islam secara kuantitatif (Mahmud, 2011). Di Indonesia tidak diketahui secara mesti kapan istilah madrasah pertama kali digunakan untuk sebuah institusi pendidikan. Hanya, melihat perkembangannya dipahami bahwa madrasah bukanlah suatu yang pribumi dalam peta dunia pendidikan di Indonesia, sebagai mana yang di tunjukan oleh istilah madrasah itu sendiri.

Madrasah dalam khazanah kehidupan manusia Indonesia merupakan fenomena budaya yang telah berusia satu abad lebih bahkan bukan suatu hal yang berlebihan madrasah telah menjadi proses sosialisasi yang relative intensif. Indikasinya adalah kenyataan bahwa wujud entitas budaya ini telah di akui dan diteriama kehadirannya, secara berangsur namun pasti ia telah memasuki arus utama pembangun bangsa menjelang akhir abad ke 20 ini. Dalam sensus kelembagaan pendidikan dasar oleh pemerintah (BAPPENAS), Madrasah ibtidaiyah (MI) secara berdampingan dengan sekolah dasar (SD) menjadi sasaran pendapatan tersebut. Masuknya model pendidikan sekolah membawa dampak yang kurang menguntungkan bagi umat islam saat ini, yang mengarah pada lahirnya dikotomi ilmu agama (islam) dan ilmu sekuler (ilmu umum dan ilmu sekuler Kristen). Dualisme model pendidikan yang konfrontatif tersebut telah mengilhami munculnya gerakan reformasi dalam pendidikan pada awal abad dua puluh. Gerakan reformasi tersebut bertujuan mengakomodasi system pendidikan sekolah ke dalam lingkungan pesantren. Corak model pendidikan ini dengan cepat menyebar tidak hanya di pelosok pulau jawa tetapi juga di luar pulau jawa dari situlah embiro madrasah lahir. Selain itu munculnya mitologi ruang pendidikan yang dukukuhkan dengan ritual pendidikan. Artinya, anak bangsa di hadapkan dengan ritual kompetensi, pemilihan sekolah favorit, penyuguhan uang "persembahan" pemakaian seragam baru, pembelian "ramuan ramuan" buku buku paket baru dan segudang ritual lainnya. Munculnya ambiguisitias yaitu kebijakan pemerintah yang sebenarnya sebagai pengelola potensi anak bangsa, namun pemerintah justru menjadi penjaga mitos pendidikan. Pemerintah dengan sangat percaya diri memilih posisi lebih berpihak pada kalangan elite, maka muncullah adigum yaitu lelang pendidikan.

Permasalahan yang di hadapi pendidikan di indonesia secara umum ini, adalah kualitas, relevansi, elitisme, dan menajemen. Berbagai indikator kuantitatif di kemukakan berkenaan dengan keempat masalah di atas antara lain analisis komparatif yang membandingkan situasi pendidikan antara Negara di kawasan asia. Keempat masalah tersebut merupakan masalah besar, mendasar, dan multidimensional, sehingga sulit di cari ujung pangkal pemecahannya. Permasalahan ini terjadi pada pendidikan secara umum di Indonesia, termasuk pendidikan islam yang di nilai justru lebih besar problematikanya. Menurut (Musrifah, 2018) pendidikan nasional mengalami permasalahan diantaranya pertama, kekeliruan filosofis yang mengartikan mutu dengan indeks prestasi, kedua, lemahnya pemberdayaan tenaga pendidik islam, ketiga, manejmen pendidikan islam bersifat 
sentralistik, strukturalistik, birokratik, keempat, sistem pembelajaran bersifat paternalistic, harismatik, mileteristik, dan monolog.

Satu pertanyaan penting yang perlu di angkat adalah bagaimana minat masyarakat terhadap lembaga pendidikan islam, di lihat dari sejarahnya setidak tidaknya ada dua faktor penting yang melatar belakangi kemunculan madrasah (Muhaimin, 2012) yaitu pertama adanya pandangan yang mengatakan bahwa system pendidikan islam tradisional di rasakan kurang biasa memenuhi kebutuhan pragmatis masyarakat, kedua adanya kekhawatiran atas cepatnya perkembangan persekolahan belanda yang akan menimbulkan pemikiran sekuler di masyarakat. Faktor lain secara umum di hadapi oleh madrasah adalah masyarakat agaknya kurang memiliki kebebasan untuk mengelola dengan caranya sendiri, karena hampir semua hal yang berkaitan dengan pendidikan sudah ditentukan oleh pemegang otoritas pendidikan. Dengan kata lain penyelenggara pendidikan nasional di lakukan secara birokratic-sentralistik, yang menempatkan madrasah sebagai penyelenggara pendidikan sangat tergantung pada keputusan birokrasi yang mempunyai jalur yang sangat panjang dan kadang kadang kebijakan yang dikeluarkannya tidak sesuai dengan kondisi madrasah setempat. Dengan demikian madrasah kehilangan kemandirian, motivasi dan inisitaif untuk mengembangkan dan memajukan lembaganya, termasuk peningkatan mutu pendidikan sebagai salah satu tujuan pendidikan nasional.

\section{METODOLOGI}

Metodelogi dalam penelitian ini adalah penelitian studi kasus dalam arti penelitian ini difokuskan pada kasus (fenomena) yang kemudian di pahami dan di analisis secara mendalam. Metode penelitian ini digunakan untuk mendiskripsikan secara holistic dan komperhensif tentang gejala dan peristiwa dalam permasalahan pendidikan islam khususnya Madrasah. Analisis data penelitian dilakukan dengan cara yaitu analisis kualitatif, analisis ini terus dilakukan pada setiap tahap penelitian, mulai dari perencanaan, pelaksanaan, dan hasil penelitian. Analisis kualitatif dilakukan dengan mendeskripsikan situasi proses pembelajaran dan pandangan subjek penelitian tentang pembelajaran sehingga peneliti memperoleh pemahaman secara holistik dan penafsiran makna kontekstual permasalahan yang terjadi di objek tersebut. Tujuan penulisan artikel ini adalah untuk mengungkapkan permasalahan yang ada pada Madrasah sehingga bisa menjadi pedoman untuk kedepannya agar madrasah bisa lebih baik dan mandiri.

\section{TEMUAN}

\section{Hasil Penelitian dari Bentuk permasalahan Pendidikan Islam di Madrasah antara lain adalah:}

1) Lemahnya akhlak siswa di Madrasah

2) Kurangnya kontribusi siswa dalam Menyiarkan Ajaran Islam di masyarakat.

3) Berkurangnya minat siswa di bandingkan pada sebelumnya, dan banyak yang memilih untuk pindah ke sekolah umum. 
Alasan mengapa masalah itu terjadi

1. Adapun penyebab permasalahan nomor satu itu terjadi setidaknya ada empat penyebab :

a) Dha'ful Iman, yaitu lemah Iman.

Iman yang mantap membuat seseorang menjadi terikat kepada segala bentuk ketentuan Alloh SWT dan tidak berani menyimpang di jalannya, karena itu manaka seseorang telah memiliki iman yang mantap dan sempurna, niscaya dia memiliki akhlak yang baik.

b) Bi'ah Al-Sayyiah, yaitu lingkungan yang buruk.

Lingkungan sangat berpengaruh terhadap manusia, jika lingkungannya buruk sangat berpotensi merubah orang menjadi orang yang buruk, begitu juga sebaliknya, salah satunya adalah TV, teman pergaulan, lingkungan keluarga dan lain sebagainya.

c) Dha'fu Al- Mutaba'ah, yaitu Lemah Kontrol.

Kerusakan akhlak seseorang diantaranya lemah control (pengawasan), baik dari diri sendiri, keluarga, pengajar, dan masyarakat luas.

d) Kemajuan teknologi.

Dampak globalisasi teknologi memang dapat memberikan dampak positif tetapi tidak dapat dipungkiri lagi bahwa hal ini juga dapat berdampak negaif bagi kerusakan moral, perkembangan internet dan ponsel teknologi tinggi terkadang dampaknya sangat berbahaya bila tidak digunakan oleh orang yang tepat.

2. Adapun penyebab permasalahan nomor dua itu terjadi karena lemahnya sistem pendidikan islam, karena sistem pendidikan islam mempunyai peran yang sangat signifikan dalam pengembangan sumber daya manusia dan pembangunan karakter, sehingga masyarakat yang tercipta merupakan cerminan masyarakat islami. Dengan demikian Islam benar-benar menjadi rahmatan lil'alamin, rahmat bagi seluruh alam.

3. Adapun penyebab permasalahan nomor tiga itu terjadi adalah :

a) Rendahnya minat peserta didik untuk memahami ilmu-ilmu agama Islam.

b) Rendahnya minat dan kemampuan peserta didik untuk bisa membaca dan memahami Al-Qur'an.

c) Peserta didik belum memiliki dasar keimanan dan ketakwaan yang kuat, sehingga mudah untuk terbawa arus.

d) Semakin banyak peserta didik yang berprilaku menyimpang dari moral agama, pergaulan bebas semakin meningkat.

e) Peserta didik terbiasa dengan narkoba, kekerasan, dan tindak anarkis.

a. Dampak dari masalah tersebut terhadap pendidikan islam

1) Adapun dampak dari permasalahan nomor satu tersebut adalah Potret pendidikan di Indonesia tercoreng oleh beberapa insiden (kasus) memalukan yang dilakukan oleh beberapa oknum pelaku pendidikan, beberapa media cetak maupun elektronik memberitakan diantaranya tawuran pelajar dan mahasiswa bukan hanya proses belajar dan mengajar yang terganggu, tetapi tidak sedikirt para pelajar dan mahasiswa terluka melawan sampai memakan korban. Penyebaran video porno baik melalui handphone, internet maupun CD/DVD sudah sangat menghawatirkan, free sek dikalangan 
pelajar, remaja Indonesia usia 10-24 tahun sudah mencapai 62 juta, 15 persen dari remaja telah melakukan hubungan seks diluar nikah, apa yang menjadi penyebab terjadinya hal tersebut terutama di dunia pendidikan kita, jawabannya adalah karena kerusakan akhlak dikalangan para pelajar dan mahasiswa (Maarif, 1987).

2) Adapun dampak permasalahan nomor dua terjadi adalah kurangnya kontribusi siswa di masyarakat, maka akan mengakibatkan buruknya pendidikan islam di masyarakat hal ini akan mengakibatkan keruwetan persoalan di tengah-tengah masyarakat seperti terjadinya tawuran pelajar, seks bebas, narkoba, dan sebagainya. Pada saat yang sama, situasi masyarakat yang buruk jelas membuat nilai-nilai yang mungkin sudah berhasil ditanamkan di tengah keluarga dan sekolah atau kampus menjadi kurang optimum. Apalagi jika pendidikan yang diterima di sekolah atau kampus juga kurang bagus, maka lengkaplah kehancuran dari pendidikan tersebut (Fakih, 2000).

3) Adapun dampak permasalahan nomor tiga terjadi adalah berdampak pada pendidikan islam yang akan datang karena peserta didik merupakan orang yang belum dewasa dan memiliki sejumlah potensi (kemampuan) dasar yang masih perlu dikembangkan. Di sisi lain pendidikan itu berfungsi membentuk kepribadian anak, mengembangkan agar mereka percaya diri dan menggapai kemerdekaan kepribadian, pendidikan itu bergerak untuk mewujudkan perkembangan yang sempurna dan mempersiapkannya dalam kehidupan, membantu untuk berinteraksi sosial yang positif di masyarakat, menumbuhkan kekuatan dan kemampuan dan memberikan sesuatu yang dimilikinya semaksimal mungkin. Juga menimbulkan kekuatan atau ruh kreativitas, pencerahan dan transparansi serta pembahasan atau analisis di dalamnya. Peserta didik merupakan ukuran dari keberhasilan suatu pendidikan. Masyarakat selalu menilai keberhasilan pendidikan dari output yang berasal dari siswa. Problematika yang muncul dari peserta didik adalah umumnya siswa yang telah belajar selama 12 tahun (SD, SMP, dan SMA), yang mana mata pelajaran agama hanya diajarkan dua jam saja dalam satu minggu, masih banyak yang belum bisa membaca Al-Qur'an dengan baik dan benar, tidak menjalankan kewajiban sholat secara rutin, tidak beribadah puasa di bulan Ramadhan, dan yang paling penting adalah kurang bisa berprilaku secara benar.

\section{Pembahasan Penelitian}

1. Kajian Pendidikan Islam

Untuk menyeimbangkan perkembangan Sekularisme, maka masyarakat muslim, terutama para Reformist berusaha melakukan reformasi melalui upaya pengembangan pendidikan dan pemberdayaan Madrasah. Menurut al-Munjid kata "Madrasah" adalah isim makan dari kata : darasa-yadrusu-darsan wa durusu wa dirasatan yang berarti : terhapus, hilang bekasnya, menghapus, menjadikan using, melatih, mempelajari. Dilihat dari pengertian ini, maka Madrasah berarti merupakan tempat untuk mencerdaskan para peserta didik, menghilangkan ketidaktauan atau memberantas kebodohan mereka, serta melatih keterampilan mereka sesuai dengan bakat, minat dan kemampuannya. Pengetahuan dan keterampilan seseorang akan cepat usang selaras dengan percepatan kemajuan ipteks dan perkembangan zaman, sehingga Madrasah pada dasarnya sebagai wahana untuk mengembangkan kepekaan intelektual dan informasi, serta memperbarui pengetahuan, sikap dan keterampilan secara berkelanjutan, agar tetap up to date dan tidak cepat usang. 
Faktor lain yang secara umum dihadapi oleh Madrasah adalah masyarakat agaknya kurang memiliki kebebasan untuk mengelola dengan caranya sendiri, karena hampir semua hal yang berkaitan dengan pendidikan sudah ditentukan oleh pemegang otoritas pendidikan. Dengan kata lain, penyelenggaraan pendidikan nasional dilkukan secara birokratik-sentralistik, yang menempatkan Madrasah sebagai penyelenggara pendidikan sangat tergantung pada keputusan birokrasi yang mempunyai jalur yang sangat panjang dan kadang-kadang kebijakan yang dikeluarkannya tidak sesuai dengan kondisi Madrasah setempat. Dengan demikian, Madrasah kehilangan kemandirian, motivasi dan inisiatif untuk mengembangkan dan memajukan lembaganya, termasuk peningkatan mutu pendidikan sebagai salah satu tujuan pendidikan nasional.

Dampak atau masalah yang utama dihadapi oleh madrasah pada umumnya yaitu :

1) Masalah identitas diri madrasah, sehingga program pengembangannya sering kurang jelas dan tidak terarah.

2) Masalah jenis pendidikan yang dipilih sebagai alternatif dasar yang akan dikelola untuk menciptakan satu sistem pendidikan yang masih memiliki titik tekan keagaman (IMTQ), tetapi IPTEKS (ilmu pengetahuan, teknologi dan seni) tetap diberi porsi yang seimbang sebagai basis mengantisipasi perkembangan masyarakat yang semakin global. Dalam arti, bagaimana membangun keseimbangan dalam porsi yang sama dan tidak saling menindih antara satu dengan yang lainnya.

3) Semakin langkanya generasi muslim yang mampu menguasai ajaran Islam, baik secara kuantitatif maupun kualitatif, apalagi sampai langka menguasai totalitas agama (akidah, syariah dan akhlak). Ini menunjukkan kemunduran kualitas ajaran Islam, yang berimplikasi pada kedangkalan pemahaman Islam dan munculnya persepsi eksklusif dan sebagainya.

4) Masalah sumber daya internal yang ada dan pemanfaatannya bagi pengembangan madrasah sendiri di masa depan.

Keempat masalah tersebut intinya terkait dengan aspek manajerial, yakni manajemen pengembangan Madrasah yang belum banyak bertolak dari visi dan misi serta tujuan dan sasaran yang jelas, sehingga pengelolaannya sering kurang arah bahkan meninggalkan identitas Madrasah sendiri. Madrasah juga bisa dan memang harus dikelola secara demikian. Apalagi Madrasah sekarang sama dengan SD sehingga diperlukan ciri khas Islam. Ciri khas ini jangan diartikan Madrasah harus mengisolasikan diri dari perkembangan zaman. Sebaliknya, dengan ciri ke Islamannya, madrasah menyongsong kemajuan zaman dengan optimis. Disinilah kita membutuhkan Madrasah percontohan dan di sini pula dana pemerintah tadi bisa digunakan (Fajar, 2010).

Surat keputusan pada tanggal 8 Maret 1819, dalam buku Karel A. Steenbrink, Gubernur Jendral Van der Capellen memerintahkan mengadakan suatu penelitian tentang pendidikan masyarakat Jawa, dengan tujuan meningkatkan kemampuan membaca dan menulis dikalangan mereka. Dari hasil penelitian tersebut diharapkan, pelaksanaan Undang-Undang dan peraturan pendidikan dapat diperbaiki. Secara khusus diteliti juga, apakah sebaiknya guru yang ada dimanfaatkan dan diberi motivasi melalui peraturan yang sesuai, atau perlu menciptakan suatu keadaan yang berbeda sama sekali. 
1) Permasalahan Madrasah dalam Pendidikan Islam

Permasalahan yang dihadapi oleh Madrasah dalam pendidikan Islam dengan melihat dari dua sisi permasalahan pokok yaitu permasalahan internal dan permasalahan eksternal. Berikut penjelasannya:

1. Permasalahan Internal

a. Profesionalisme Guru

Salah satu komponen penting dalam kegiatan pendidik dan proses pembelajaran adalah pendidik atau guru. Betapapun kemajuan teknologi telah menyediakan berbagai alat untuk meningkatkan efektifitas proses pembelajaran, namun posisi pendidik / guru merupakan variabel penting bagi keberhasilan pendidik. Menyadarkan guru bahwa pekerjaan mereka merupakan pekerjaan professional merupakan "upaya awal" yang harus dilakukan dalam rangka pencapaian standar proses pendidikan sesuai dengan harapan (Sanjaya, 2010).

Masih adanya anggapan bahwa semua orang bisa menjadi guru, asalkan mereka dapat menyampaikan materi pelajaran, hal itu merupakan suatu pandangan yang keliru dan harus diluruskan. Sebab tugas dan fungsi guru itu bukan hanya sekedar penyampaian materi saja, akan tetapi adalah suatu proses perubahan sikap dan prilaku peserta didik sesuai dengan tujuan yang diharapakan. Oleh karena itu dalam proses pembelajaran terdapat kegiatan membimbing, melatih keterampilan, memotivasi agar siswa dapat memecahkan berbagai persoalan kehidupan. Untuk itu para ahli pendidikan telah merumuskan beberapa criteria guru / pendidik yang profesioanl tersebut sebagai berikut :

1) Memiliki kemampuan dan keahlian dalam bidangnya sesuai dengan profesinya.

2) Memiliki ilmu yang mendalam untuk menunjang profesinya dan ilmu tersebut hanya mungkin diperoleh melalui lembaga pendidikan keguruan.

3) Memiliki kemampuan profesinya didasrkan kepada latar belakang pendidikan yang diakui oleh masyarakat.

4) Memiliki kepekaan terhadap dinamika perkembangan masyarakat, baik perkembangan sosial, budaya, politik, maupun perkembangan teknologi. Berdasarkan kriteria guru/pendidik profesional tersebut, maka jelaslah bahwa profesi guru bukanlah sekedar usaha sambilan atau pekerjaan ojekan (moor-lighter). Tetapi betul-betul harus didasarkan pada bidang keilmuan, dilakukan dengan penuh kesadaran dan penuh rasa tanggungjawab (amanab). Namun kenyataan di lapangan justru menunjukkan adanya guru / pendidik yang secara umum belum dapat dikatakan professional. Hal ini antara lain dipengaruhi oleh latar belakang pendidik rata-rata yang kualitasnya masih rendah., di samping motivasi menjadi guru/pendidik lebih didasarkan pada motivasi keagaman. Menurut Abuddin Nata permasalahan tersebut disebabkan oleh : 
1) Banyak diantara pendidik /guru berasal dari lembaga-lembaga non kependidikan.

2) Mereka direkrut menjadi tenaga pendidik karena alasan kebutuhan atau alasan-alasan lain yang sifatnya jauh dari pertimbangan akademik dan kompetensi professional (Nata, 2013).

b. Metodologi Pembelajaran

Pandangan filosofis pendidikan, metode merupakan alat yang dipergunakan untuk mencapai tujuan pendidikan. Alat itu mempunyai fungsi ganda yaitu bersifat " $p$ oli pragmatis" dan "monopragmatis". Menyikapi tentang metodologi pembelajaran yang dipergunakan oleh sebahagian guru agama selama ini telah banyak menuai kritik, sebagaimana diungkap oleh muhaimin dalam bukunya "Paradigma Pendidkan Islam" bahwa : Metodologi Pendidikan Agama Islam tidak kunjung berubah, ia berjalan secara konvensional-tradisional dan monoton. Sementara dalam proses pembelajaran metode itu sangat memegang peranan penting. Keberhasilan suatu pembelajaran sangat ditentukan oleh cara guru memberikan pembelajaran, karena tujuan pembelajaran hanya mungkin dapat dicapai dengan baik melalui penggunaan metode pembelajaran. Bahkan Mahmud Yunus secara ekstrim pernah mengatakan bahwa penguasaan terhadap metodologi pembelajaran jauh lebih penting dari pada pemberian materi pembelajaran.

\section{c. Kurikulum}

Kebijakan pemerintah untuk meningkatkan mutu, relevansi dan efesiensi dalam system pendidikan nasional terus dilaksanakan. Di antara upaya yang telah dilakukan untuk meningkatkan mutu dan relevansi pendidikan tersebut adalah dengan penyempurnaan kurikulum. Perubahan dan penyempurnaan kurikulum merupakan salah satu upaya untuk mendongkrak mutu pendidikan. Namum perubahan dan penyempurnaan kurikulum yang dilakukan selama ini nampaknya belum menunjukkan hasil yang signifikan terhadap peningkatan mutu pendidikan tersebut.

Berbagai analisa pakar pendidikan ada sinyalemen bahwa pendidikan nasional kita dewasa ini sedang dihadapkan pada berbagai krisis yang perlu mendapat penanganan yang cukup serius. Keadaan darurat tersebut (krisis pendidikan) dibuktikan dengan membawa fakta baru dari lapangan yang menampilkan data tentang rendahnya mutu pendidikan di Indonesia. Menurut Fasil Jalal dalam buku Reformasi Pendidikan dalam Konteks Otonomi Daerah, menyatakan bahwa rendahnya mutu pendidikan selama ini antara lain disebabkan oleh kurikulum yang kurang sesuai dengan kebutuhan dan pembangunan. Kerangka pemikiran tersebutlah, pemerintah menggagas kurikulum baru yang diberi nama dengan Kurikulum Tingkat Satuan Pendidikan (KTSP). Melalui KTSP ini pemerintah berharap jurang pemisah yang semakin menganga antara pendidikan dan pembangunan serta kebutuhan dunia kerja dapat teratasi (Mulyasa, Kurikulum Tingkat Satuan Pendidiakan, 2011).

Oleh karena itu dikatakan bahwa KTSP merupakan salah satu wujud reformasi pendidikan yang memberikan otonomi kepada sekolah dan satuan pendidikan untuk mengembangkan kurikulum sesusai dengan potensi, tuntutan dan kebutuhan masingmasing. Dalam hal ini dapat dikatakan bahwa bagaimanapun bagusnya suatu kurikulum, 
maka aktualisasinya sangat ditentukan oleh protesinalisme guru dalam melaksanakan pembelajaran.

\section{Permasalahan Eksternal}

Permasalahan eksternal pendidikan Islam pada dasarnya dipengaruhi oleh dimensidimensi perkembangan dari luar, seperti : sosial, budaya, ekonomi, politik, bahkan juga dipengaruhi oleh dimensi global. Dari berbagai permasalahan eksternal pendidikan Islam dewasa ini, maka yang akan dikemukakan hanya dua permasalahan yang penulis anggap penting:

a. Permasalahan Dikotomi Pendidikan

Meskipun dewasa ini system pendidikan Islam sudah dibenahi dan disempurnakan, namun dalam sistem kelembagaan masih dirasakan adanya dualisme dalam pendidikan, yaitu pendidikan umum dan pendidikan agama agaknya merupakan warisan dari pemikiran Islam klasik yang memilih antara ilmu umum dan ilmu agama atau ilmu ghirussy syariah dan ilmu syari'ah, seperti yang terlihat dalam konsep al-Ghazali tentang ilmu. Dualisme atau dikotomi dalam sistem pendidikan yang berlaku sekarang merupakan permasalahan yang harus menjadi pemikiran, bukan saja karena sampai saat ini belum ditemukan solusinya, melainkan juga semakin menimbulkan kecemburuan sosial yang pada akhirnya akan menimbulkan perbedaan yang semakin mencolok. Menurut Syafi'i Ma'arif, dikotomi pendidikan pada dasarnya akan melahirkan sosok manusia yang pincang.

Keinginan untuk menyatukan penanganan dalam suatu sistem pendidikan nasional, betapapun baiknya dan wajarnya keinginan tersebut, seringkali masih merupakan kerumitan tersendiri. Permasalahannya terletak dalam kekhawatiran akan jaminan pegangan yang sungguh-sungguh dan professional, jika pendidikan Islam tersebut tidak ditangani oleh pihak kaum agama (Depertemen Agama).

b. Permasalahan Globalisasi

Globalisasi sering dipahami sebagai suatu kekuatan raksasa yang akan mempengaruhi tata kehidupan dunia secara menyeluruh, simultan dan berdampak multiplayer effects. Dengan pengaruh globalisasi, dunia terasa menjadi kecil dan transparan. Hampir tidak ada rahasia suatu Negara yang tidak diketahui oleh Negara lain. Apa yang terjadi di suatu Negara ini, hari itu juga dapat diketahui oleh Negara lain. Bila globalisasi tersebut dikaitkan dengan pendidikan berarti terintegrasinya pendidikan nasional ke dalam pendidikan dunia. Oleh karena itu globalisasi sudah mulai menjadi permasalahan actual dalam pendidikan, terutama sekali menyangkut dengan kualitas output pendidikan dimasa-masa mendatang. Seperti diketahui, di era globalisasi ini telah terjadi penggeseran paradigma tentang keunggulan suatu Negara dari keunggulan komparatif (comparative advantage) kepada keunggulan komparatif (comparative advantage) yang bertumpu pada kekayan sumber daya alam (SDA), sementara keunggulan kompetitif bertumpu pada pemilikan sumber daya manusia (SDM) yang berkualitas (Kuntowijiyo, 2011).

Dalam konteks penggeseran paradigma keunggulan tersebut, pendidikan Islam akan menghadapi situasi kompetitif yang sangat tinggi, karena harus berhadapan dengan kekutan pendidikan global. Hal ini dengan erat kaitannya 
dengan kenyataan bahwa globalisasi justru melahirkan semangat cosmopolitanisme, dimana masyarakat boleh jadi akan memilih sekolah-sekolah diluar negeri sebagai tempt pendidikan anak mereka, terutama jika sekola-sekolah dalam negeri secara kompetitif berkualitas rendah (underqulity). Kecendrungan ini sudah mulai telihat pada perguruan tunggi dan bukan mustahil akan merambah pada tingkat sekolah menengah. Apabila persoalannya hanya sebatas tantangan kompetitif, maka masalahnya tidak akan menjadi krusial (gawat), tetapi kalau batasan-batasan atau ketentuan-ketentuan yang nantinya sekolah berstandar internasional sebagai prasyarat output pendidikan untuk memperoleh akses kebursa tenaga kerja global, maka hal tersebut pasti akan menjadi masalah yang cukup serius bagi pendidikan Islam.

Sementara pendidikan Islam masih bergumul dengan permasalahanpermasalahan internal mereka, sehingga permasalahan kualitas untuk mencapai mutu inetrnasioanal masih merupaka perjuangan yang cukup panjang dan melelahkan. Menyikapi pengaruh globalisasi terhadap pendidikan Islam, maka sudah seharusnya sejak dini pakar pendidikan Islam memikirkan tentang peningkatan kualitas yang secara kompetitif dapat diandalkan, baik lembaganya maupun dari proses pendidikannya. Kalau selama ini kita masih terbuai dengan nyanyian romantis historis, dimana kita banggga pernah memiliki para pemikir dan ilmuan-ilmuan besar serta mempunyai kontribusi yang besar pula bagi pembanguanan peradaban dan ilmu pengetahuan dunia, maka sekarang nyanyian romantis tersebut harus di aransmen baru, ditata kembali dengan memberi ruh Islam ke dalam kualitas pendidikan tersebut.

\section{3) Analisis Permasalahan Pendidikan Islam di Madrasah}

a) Analisis siswa atau peserta didik

Peserta didik adalah anggota masyarakat yang berusaha mengembangkan potensi diri melalui pembelajaran yang tersedia pada jalur jenjang dan jenis pendidikan tertentu. Omar Hamalik di kutip dari Ari Hidayat dan Imam Mahali mendefinisikan peserta didik sebagai suatu kompenen masukan dalam sistem pendidikan yang selanjutnya diproses dalam proses pendidikan, sehingga menjadi manusia berkualitas. Adapun tahapan-tahapan pengelolan peserta didik menuurut Ari Hidayat dan Imam Machali adalah sebagai berikut:

1. Analisis kebutuhan peserta didik.

2. Rekruitmen peserta didik.

3. Seleksi peserta didik.

4. Orientasi.

5. Penempatan peserta didik.

6. Pembinaan dan penagembangan peserta didik.

7. Pencatatan dan pelaporan.

8. Kelulusan dan Alumni.

Oleh karena itu, manajemen kesiswaan pendidikan Islam bila dilihat dari segi tahapan dalam masa studi di sekolah/madrasah dapat dibagi menjadi tiga tahapan, yaitu, penerimaan siswa baru, preoses pembelajaran dan persiapan studi lanjut atau bekerja. Dengan istilah lain, tiga tahapan tersebut dapat disebut denga 
tahapan penjaringan, pemprosesan dan pendistribusian. Semua tahapan tersebut membutuhkan pengelolaan secara maksimal agar mendapatkan hasil yang maksimal pula.

b) Analisis tenaga kependidikan

USPN No. 20 Tahun 2003 menyebutkan bahwa yang dimaksud dengan pendidikan adalah tenaga kependidikan yang berkualifikasi sebagai guru, dosen, konselor, pamong belajar, widyaiswara. Tutor, instruktur, fasilitator, dan sebutan lain yang sesuai dengan kekhususannya serta berpartisipasi dalam menyelenggarakan pendidikan. Sedangkan tenaga kependidikan adalah anggota masyarakat yang mengabdikan diri dan diangkat untuk menunjang penyelenggaraan pendidikan. Peranan guru yang sangat penting tersebut bisa menjadi potensi besar dalam memajukan atau meningkatkan mutu pendidikan Islam, atau sebaliknya bisa juga menghancurkannya. Ketika guru benar-benar berlaku profesional dan dapat mengelola pendidikan dengan baik, tentunya mereka semakin bersemangat dalam menjalnkan tugasnya bahkan rela melakukan inovasi pembelajarn untuk kesuksesan pembelajaran peserta didik (Qomar, 2010).

c) Analisis sarana fisik sekolah

Sarana pendidikan adalah segala sesuatu yang meliputi peralatan dan perlengkapan yang langsung digunakan dalam proses pendidikan di sekolah seperti gedung, ruangan, meja, kursi, alat peraga, buku pelajaran dan lain-lain. Sedangkan prasarana semua kompenen yang secara tidak langsung menunjang jalannya proses pembelajaran di lembaga pendidikan tersebut seperti jalan menuju sekolah, halaman sekolah, tata tertip sekolah dan lain-lain.

Oleh karena itu, sarana dan prasarana pendidikan Islam seharusnya diupayakan semaksimal mungkin agar lembaga pendidikan Islam Memiliki daya tarik yang khas. Jika terjadi demikian, maka posisi tawar lembaga tersebut terhadap masyarakat sekitar sangatlah tinggi. Hal ini mungkin terjadi jika sarana dan prasarana ini mendapat perhatian besar dari manajer pendidikan Islam mulai tahap perencanaan sampai pada perawatan / pemeliharaan.

d) Analisis kurikulum, materi pendidikan dan proses belajar mengajar

Selama ini kurikulum di anggap sebagai penentu keberhasilan pendidikan, termasuk pendidikan Islam. Karena itu, perhatian para guru, dosen, kepala sekolah/madrasah, ketua rektor, maupun praktisi pendidikan terkonsentrasi pada kurikulum. Padahal kurikulum bukanlah penentu utama. Dalam kasus pendidikan di Indonesia misalnya. Problem yang paling besar di hadapi bangsa ini sesungguhnya bukan problem kurikulum, meskipun bukan berarti kurikulum tidak menimbulkan problem, namun masalah kesadaran merupakan masalah yang besar. Yaitu lemahnya kesadaran untuk berprestasi, kesadaran untuk sukses, kesadaran untuk meningkatkan SDM, kesadaran untuk menghilangkan kebodohan, maupun kesadaran untuk berbuat yang terbaik (Qomar, 2010).

Menurut Mujamil Qomar yang dikutip dari Al-Syaibani mengutarakan beberapa ciri-ciri kurikulum pendidikan Islam, yaitu :

1. Menonjolkan tujuan agama dan akhlak pada sebagi tujuan, kandungan, metode alat dan tekniknya.

2. Memiliki perhatian yang luas dan kandungan yang menyeluruh. 
3. Memiliki keseimbangan antara kandungan kurikulum dari segi ilmu dan seni, kemestian, pengalaman dan kegiatan pengajaran yang beragam.

4. Berkecendrungan pada seni halus, aktivitas pendiddkan, jasmani, latihan militer, pengetahuan teknik latihan kejuruan dan bahasa asing untuk perorangan maupun mereka yang memiliki kesediaan, bakat dan keinginan.

5. Keterkaitan kurikulum dengan kesediaan, minat, kemampuan, kebutuhan, dan perbedaan perorangan di antara mereka.

Ciri-ciri ini menggambarkan adanya berbagai tuntutan yang harus ada dalam kurikulum pendidikan Islam. Tuntutan ini terus berkembang sesuai dengan tantangan zaman yang sedang dihadapi. Tantangan pendidikan Islam dizaman sekarang tentu sangat berbeda dengan zaman klasik dulu. Tantangan dizaman sekarang tentu lebih kompleks. Kurikulum pendidikan harus dirancang dengan sebagus mungkin untuk menghasilkan output yang memuaskan.

e) Analisis administrasi dan keuangan sekolah

Selama ini ada kesan bahwa keuangan adalah segalanya dalam memajukan suatu lembaga pendidikan. Tanpa dukungan finasial yang cukup, manajer lembaga pendidikan seakan tidak bisa berbuat banyak dalam upaya memajukan lembaga pendidikan yang dipimpinnya. Sebab mereka berpikir semua upaya memajukan senantiasa harus dimodali dengan uang. Upaya memajukan kompenen-kompenen pendidikan tanpa disertai dukungan uang akan pasti mandek atau macet di tengah jalan. Setidaknya ada dua hal yang menyebabkan timbulnya perhatian yang besar pada keuangan yaitu (Mulyasa, E, 2013) :

1. Keuangan temaasuk kunci penentu kelangsungan dan kemajuan lembaga pendidikan. Kenyataan ini mengandung konsekuensi bahwa programprogram pembaruan atau pengembangan pendidikan bisa gagal dan berantakan manakala tidak didukung oleh Ldana yang memadai.

2. Lazimnya uang dalam jumlah besar sulit sekali didapatkan khususnya lembaga pendidikan swasta yang baru berdiri.

f) Analisis lingkungan sosial masyarakat

Lembaga pendidikan Islam perlu menangani masyarakat atau hubungan lembaga pendidikan Islam dengan masyarakat. Kita harus menyadari bahwa masyarakat memiliki peranan yang sangat penting terhadap keberadaan, keberlangsungan bahkan kemajuan lembaga pendidikan Islam. Setidaknya salah satu parameter penentu nasib lembaga pendidikan Islam adalah masyarakat. Bila ada lembaga pendidikan Islam maju, hampir bisa dipastikan salah satu faktor keberhasilan adalah keterlibatan masyarakat yang maksimal. Begitu pula sebaliknya, bila ada lembaga pendidikan Islam yang memperihatinkan, salah satu penyebabnya bisa jadi masyarakat enggang mendukung. Sikap masyarakat ini bisa jadi akibat dari hal lain dalam kaitannya dengan lembaga pendidikan Islam, baik yang bersifat internal maupun eksternal.

Masyarakat memiliki posisi ganda dalam lembaga pendidikan Islam, yaitu sebagai objek dan sebagi subjek yang keduanya memiliki makna fungsional bagi 
pengadaan lembaga pendidikan Islam. Ketika lembaga pendidikan Islam sedang melakukan promosi penerimaan siswa/santri dan mahasiswa baru maka masyarakat menjadi objek mutlak di butuhkan. Sementara itu respon terhadap promosi itu menempatkan mereka sebagai subjek yang memiliki kewenangan penuh untuk menerima atau menolaknya.

g) Analisis peranan pemerintah dan Yayasan

Dalam menghadapi kebijakan pemerintah yang dinilai kurang berpihak pada pengembangan lembaga pendidikan, pengelola harus mampu memiliki jiwa untuk berbesar dan menanggung apa yang terjadi di kemudian hari terhadap terhadap kebijakan tersebut (Prasetyo, 2011).

Umumnya ketidak sesuaian kebijakan dengan apa yang ada di atas kertas dengan apa yang ada di lapangan dikarenakan tidak adanya kebijakan pendukung. Misalnya seperti penerapan kebijakan dalam menjalankan standar nasional pendidikan dalam bidang proses pembelajaran seperti yang tertuang dalam permendiknas No. 22,23 dan 24 tahun 2006, sekolah atau madrasah melaksanakan proses pembelajaran yang terencana dibuktikan dengan adanya para guru yang membuat silabus dan RPP. Kebijakan ini sebenarnya adalah langkah maju yang dilakukan oleh pemerintah dalam upaya pembelajaran yang efektif. Namun awalnya kebijakan ini juga berjalan tersendak-sendak dikarenakan ketika menerima kebijakan tersebut para pengelola madrasah merasa kelebihan karena kebijakan tersebut tidak di ikuti dengan kebijakan pendukung seperti pengadaan pelatihan pembuatan silabus dan RPP yang merata diseluruh Indonesia, bantuan dana serta teknologi informasi dan komunikasi yang berkaitan dengan hal tersebut.

\section{KESIMPULAN}

Pendidikan Islam dihadapkan dan terperangkap pada persoalan yang sama, bahkan apabila diamati dan kemudian disimpulkan pendidikan Islam terkukung dalam kemunduran, keterbelakangan, ketidak berdayaan, dan kemiskinan, sebagaimana pula yang dialami oleh sebagian besar negara dan masyarakat Islam dibandingkan dengan mereka yang non Islam. Katakan saja, pendidikan Islam terjebak dalam lingkaran yang tak kunjung selesai yaitu persoalan tuntutan kualitas, relevansi dengan kebutuhan, perubahan zaman, dan bahkan pendidikan apabila diberi "embel-embel Islam", dianggap berkonotasi kemunduran dan keterbelakangan, meskipun sekarang secara berangsur-angsur banyak diantara lembaga pendidikan Islam yang telah menunjukkan kemajuan.

Terlepas dari berbagai problema yang dihadapi, baik yang berasal dari dalam sistem seperti masalah manajemen, kualitas input dan kondisi sarana prasarananya, maupun dari luar sistem seperti persyaratan akreditasi yang kaku dan aturan-aturan lain, madrasah yang memiliki karakteristik khas yang tidak dimiliki oleh model pendidikan lainnya itu menjadi salah satu tumpuan harapan bagi manusia modern untuk mengatasi keringnya hati dari nuansa keagamaan dan menghindarkan diri dari fenomena demoralisasi dan dehumanisasi yang semakin merajalela seiring dengan kemajuan peradaban teknologi dan materi. Sebagai jembatan antara model pendidikan pesantren dan model pendidikan sekolah, madrasah menjadi sangat fleksibel diakomodasikan dalam berbagai lingkungan. 
Dari uraian di atas, menegaskan bahwa lembaga-lembaga pendidikan Islam harus mendesain model-model pendidikan alternatif yang sesuai dengan kebutuhan perkembangan sekarang ini. Yang diharapkan dapat menghadapi dan menjawab tantangan perubahan yang terjadi dalam kehidupan masyarakat baik sosial maupun kultural menuju masyarakat Indonesia baru. Untuk menjawab pertanyaan ini, meminjam prinsip hakekat pendidikan Islam yang digunakan Hasim Amir, yang mengemukakan bahwa pendidikan Islam adalah pendidikan yang idealistik, yakni pendidikan yang integralistik, humanistik, pragmatik dan berakar pada budaya kuat.

\section{REFERENSI}

Burhanuddin, J. (2011). Mencetak Muslim Modern Peta Pendidikan Nasional Indonesia . Jakarta: PT Raja Grapindo persada.

Fajar, A. M. (2010). Madrasah dan tantangan Modernitas. Bandung: Mizan.

Fakih, M. (2000). Runtuhnya Teori Pembangunan dan Globalisasi. Yogyakarta: Inset Press dan Pustaka Belajar.

Kuntowijiyo. (2011). Muslin Tanpa Mesjid Esai-Esai Agama Budaya dan Politik dalam Bingkai Strukturalisme Transcental. Bandung: Mizan.

Maarif, A. S. (1987). Masalah Pembaharuan Pendidikan Islam. Yogyakarta: LPM UII.

Mahmud. (2011). Pemikiran Pendidikan Islam. Bandung: Pustaka Setia.

Muhaimin. (2012). Pengembangan Kurikulum Pendidikan Agama Islam di Sekolah Madrasah dan Perguruan Tinggi. Jakarta: Rajawali Press.

Mulyasa, E. (2013). Menajemen Berbasis Sekolah : Konsep Strategi dan Implememtasi. Bandung: Remaja Rosdakarya.

Mulyasa, E. (2011). Kurikulum Tingkat Satuan Pendidiakan. Bandung: PT Remaja Rosdakarya.

Musrifah. (2018). Analisis Kritis Permasalahan Pendidikan Islam Indonesia di Era Global. Journal of Islamic Studies and Humanities, Vol. 3, No.1.

Prasetyo, M. T. (2011). Strategi Pengelolaan SD/MI Visioner. Malang: UIN Maliki Press.

Qomar, M. (2010). Menajmen pendidikan Islam. Bandung: Erlangga.

Sanjaya, W. (2010). Strategi Pembelajaran: Berorientasi Proses Pendidikan. Jakarta: Prenada Media. 